\title{
Decriminalizing Delinquency: The Effect of Raising the Age of Majority on Juvenile Recidivism
}

\author{
Charles E. Loeffler and Ben Grunwald
}

\begin{abstract}
In the last decade, a number of states have expanded the jurisdiction of their juvenile courts by increasing the maximum age to 18 . Proponents argue that these expansions reduce crime by increasing access to the beneficial features of the juvenile justice system. Critics counter that the expansions risk increasing crime by reducing deterrence. In 2010, Illinois raised the maximum age for juvenile court for offenders who commit a misdemeanor. By examining the effect of this law on juvenile offenders in Chicago, this paper provides the first empirical estimates of the consequences of recent legislative activity to raise the age of criminal majority. Applying a difference-in-differences design with multiple control groups, we find little evidence of an effect. Our results suggest that-contrary to the expectations of both advocates and opponents-increasing the maximum age for juvenile court does not affect juvenile recidivism.
\end{abstract}

\section{INTRODUCTION}

Historically, children over 14 have been presumptively culpable for their crimes. In the late 19 th century, juvenile justice reformers advocated for the creation of a separate judicial system that emphasized rehabilitation rather than punishment and judicial discretion rather than procedural formality. This movement was driven by concerns that juvenile offenders were different from adult offenders and might benefit from alternative forms of judicial processing (Tanenhaus 2002, 2004). The juvenile court

CHARLES E. LOEFFleR is the Jerry Lee Assistant Professor of Criminology at the University of Pennsylvania. BeN GRUNWALd is a lecturer in law and Bigelow Teaching Fellow at the University of Chicago Law School. We are grateful for the comments from Shawn Bushway, Ben Hansen, John MacDonald, Daniel Nagin, an anonymous referee, and participants at the 2013 Conference on Empirical Legal Studies and the 2014 American Society of Criminology annual meeting. We are also grateful to Timothy Lavery at the Chicago Police Department for providing the data used in this paper. 
system spread rapidly throughout the United States. Just a generation after the first was established in Illinois in 1899, juvenile courts could be found in nearly all 50 states (McCord, Widom, and Crowell 2001).

Despite this rapid and widespread adoption, the juvenile justice system began contracting in the 1970s. Growing fears of juvenile crime and skepticism about rehabilitation led many states to reconsider the wisdom of processing juveniles with serious offenses in what appeared to be a lenient juvenile justice system (Feld 1999; Fox 1996; Zimring 1998; Cook and Laub 2002). States moved more and more juveniles into the adult justice system through three kinds of legislative changes. They created statutes that required or permitted juvenile judges to transfer adolescents with serious offenses to adult court. They created direct-file procedures, which empowered prosecutors to charge juveniles with serious offenses in adult court without judicial approval. And a number of states lowered the maximum age for juvenile court-often called the age of majority-for some or all offenses. Taken together, these changes precipitated a large-scale recriminalization of juvenile offending, transferring tens of thousands of cases each year to the adult criminal justice system (Rubin 2003, P2-2).

We are now beginning to see another shift in the tides. There is significant expansionist advocacy to push the age of majority back up to 18 and, thus, to bring offenders between the ages of 16 and 18 back into the juvenile court system (Brown 2012; Moore 2011; Schwartz 2013). Several states, including Illinois, Connecticut, Mississippi, Massachusetts, and New Hampshire, have already done so.

Empirical questions play an important role in the public debate on age-of-majority legislation. Proponents argue that raising the age, and thus expanding the juvenile justice system, will reduce crime by increasing access to treatment opportunities and by decreasing the harmful effects of processing juveniles in the adult system (for example, victimization and public criminal records) (Ingram 2007; Hlavach 2013; Chicago Sun-Times 2013; Ferdinand 2002; Dixon 2009; Byrd 2008; Amelinckx and Redmond 2013). They further argue that the decrease in crime will offset the increased costs of processing additional juveniles in the more expensive juvenile justice system (Henrichson and Levshin 2011; Morse 2007; Roman 2006; Timberlake 2009). Opponents counter that older teenagers engaged in serious offending are more appropriately handled in the adult system (Lord 2008) and that raise-the-age legislation may increase juvenile crime rates (Birckhead 2008; Backus 2011) and burden 
state budgets with the higher costs of juvenile processing (Wiser 2009; Morse 2007).

This paper explores these empirical questions by providing the first estimates of the effect of recent raise-the-age legislation on juvenile recidivism. In 2010, Illinois raised the age of majority for misdemeanor crimes from 17 to 18 . As a result, 17-year-old offenders charged with a misdemeanor who would have been processed in the adult system before 2010 are now processed in the juvenile system. We apply a differencein-differences (DID) design to estimate the effect of the law on the recidivism of 17-year-old arrestees. We compare the change in recidivism among 17-year-old arrestees before and after 2010 with the change in recidivism among 16- and 18-year-old arrestees (who were unaffected by the change in law) during that same period. The results suggest thatcontrary to the expectations of both its advocates and opponents- the change in law had no effect on recidivism.

To ensure the robustness of our results, we apply the DID design to two different subsamples of the data. First, we fitted the model to the subset of suspects arrested within 60 days of their 17 th or 18 th birthday. Second, we fitted the model to a subset of suspects arrested within 60 days of the change in law (January 1, 2010). Both of these alternative specifications increase the comparability of the treatment and control groups and remove some potential unobserved sources of bias.

Our analysis improves on the research design of prior studies and reinforces and extends their findings. First, prior studies of changes to the jurisdiction of the juvenile court have formed control groups with juveniles from other states or juveniles of substantially different ages in the same state. Our detailed individual-level data permit control groups of offenders from the same city who are no more than 120 days apart in age. Second, the few studies that use better-matched control groups (for example, Hjalmarsson 2009; Lee and McCrary 2009) examine time periods during which there is no change to the jurisdiction of the juvenile court. Our study strengthens the causal inference in prior work by combining a plausible control group with a change to the age of majority. Third, our study examines the effect of raise-the-age legislation on the subset of juveniles who are arrested and processed and who thus experience firsthand the effects of the law. Our results suggest that offending rates remain unchanged even for this subset of juveniles. Fourth, our study extends the findings of prior research to a new population. Until now, scholars have evaluated the effect of changing the age of majority 
only for serious felonies, yet misdemeanors account for the vast majority of all juvenile offenses.

\section{PRIOR LITERATURE}

Two areas of academic research provide evidence on the effects of raising the age of majority on juvenile crime. The first examines the effect on aggregate offending of legislative enactments that shrank the jurisdiction of the juvenile justice system during the contractionary period that began in the 1970s.

Singer and McDowall (1988) use an interrupted-time-series design to examine the effect of a 1978 New York State law that lowered the age of exclusive jurisdiction for the juvenile court to 13 for the most serious charges (namely, murder, kidnapping, rape, burglary, robbery, and aggravated assault). The authors use 13- to 15-year-olds in New York as the treatment group and use 16- to 19-year-olds in New York and 13- to 15 -year-olds in Philadelphia as controls. Jensen and Metsger (1994) examine the effect of a 1981 law in Idaho that required juveniles between the ages of 14 and 18 charged with serious crimes (namely, murder, robbery, forcible rape, and mayhem) to be transferred to the adult system. The authors compare the rate of total juvenile arrests in Idaho in the 4 years before and after the statute was enacted with the rate of total juvenile arrests during that period in Wyoming and Montana. Risler, Sweatman, and Nackerud (1998) examine the effect of a 1994 Georgia law requiring the transfer of juveniles over 13 years of age who were charged with the most serious criminal offenses (namely, murder, manslaughter, rape, child molestation, and armed robbery). The authors compare the total juvenile arrest rates in Georgia in the 2 years before and after the law went into effect. A final study examines the effect of direct-file statutes (Steiner and Wright 2006), which empower prosecutors to transfer juveniles with serious offenses to the adult system without judicial approval. The authors apply a multiple-interrupted time-series model, comparing the juvenile arrest rates for violent crimes in the 14 states that enacted direct-file statutes and the 10 states that did not. The four studies find little evidence of a deterrent effect on the targeted offenses.

Taken together, the null findings in the literature provide little evidence that the location of the age boundary between the juvenile and adult systems has a large effect on juvenile offending (Bishop 2000; Red- 
ding 2010). However, two methodological limitations temper this conclusion. First, the counterfactuals used in this literature are limited. One study uses 16- to 19-year-olds in the same state as controls for 13- to 15 -year-olds and also uses 13- to 15-year-olds in a similar jurisdiction. Another study does not use a control group, and two use juveniles in states that did not enact a transfer or direct-file statute as controls. It is difficult to determine whether these control groups provide valid information about the trend the treatment groups would have taken in the absence of the relevant legislative enactment. Second, prior work on legislative changes to the jurisdiction of the juvenile court examines only the offending rate for all juveniles and not the recidivism of juveniles who are arrested. It is reasonable to expect a greater effect on the subset of juveniles who are arrested and processed, as only they experience the effects of the law firsthand.

While no studies have yet examined the effect on recidivism of a legislative change that raises or lowers the age of majority for all misdemeanor or felony crimes, a related literature compares the recidivism of juveniles transferred to the adult system with those retained in the juvenile system. In one of the earliest studies, Fagan (1996) examines reoffending among juveniles arrested for robbery and burglary in two adjacent jurisdictions with different age thresholds for mandatory transfer. After controlling for differences in observable case characteristics (for example, sex, race, number of prior offenses, age at first offense, and offense severity), Fagan finds that 15- and 16-year-old robbery suspects tried as adults in New York City were 18 percent more likely than robbery suspects tried as juveniles in New Jersey to be rearrested. No effect was observed for burglary suspects.

Bishop and colleagues have published several studies comparing the recidivism rates of juveniles who are transferred to the adult system with those who are not (Bishop et al. 1996; Winner et al. 1997). In one study (Bishop et al. 1996), they match transferred and nontransferred juveniles on observable covariates (for example, number of prior offenses, offense seriousness, sex, race, and age). The authors find that 1 -year rearrest rates among transferred juveniles were 22 percent higher. Except with respect to property offenders, the authors report similar results in a 7-year follow-up study (Winner et al. 1997, p. 558).

More recent matching studies examine a wider range of offenses covered by transfer statutes. They find higher recidivism rates among transferred youth (Myers 2003; Lanza-Kaduce et al. 2005; Fagan, Kupchik, 
and Liberman 2007) and some evidence of treatment effect heterogeneity (Loughran et al. 2010; Fagan, Kupchik, and Liberman 2007).

It is difficult to determine whether these differences between transferred and nontransferred juveniles reflect a true effect of transfer or merely unobserved selection bias (McGowan et al. 2007; Mulvey and Schubert 2012). To address this concern, scholars have applied a regression discontinuity design. Recognizing that nearly all adolescents under 18 years of age arrested in Florida are processed in the juvenile system and nearly all adolescents over 18 are processed in the adult system, Lee and McCrary (2009) examine adolescents who were arrested just a few weeks before and a few weeks after their 18th birthday. The authors report relatively little evidence that processing juveniles in the adult system has a large effect on recidivism, a finding echoed by a similar regression discontinuity studies (Hjalmarsson 2009; Loeffler and Grunwald 2015).

Taken together, most studies of recidivism find that processing juveniles in the adult system increases recidivism, albeit with significant evidence of effect heterogeneity. This empirical result has played an important role in contemporary debates about age-of-majority reform. Advocates frequently cite the higher recidivism rates among juveniles transferred to the adult justice system as justification for raising the age of majority for all juvenile offenders (Ingram 2007; Hlavach 2013; Chicago Sun-Times 2013; Ferdinand 2002; Dixon 2009; Byrd 2008; Amelinckx and Redmond 2013). Similarly, scholars suggest that a higher age of majority should produce lower rates of recidivism (Cauffman 2012; Farrington, Loeber, and Howell 2012), with some scholars further suggesting that the observed double-digit differences in recidivism between transferred and nontransferred juveniles could be mirrored by similar reductions in recidivism if the age of majority is raised for all offenses (Deitch, Breeden, and Weingarten 2012; Henrichson and Levshin 2011; Roman 2006).

The applicability of previous research findings to the contemporary policy discussion, however, is unknown given their focus on transferred juveniles, who represent a small fraction of all juvenile offenders. In 2010, for example, less than 1 percent of all juvenile court petitions and less than 1 percent of all delinquency cases resulted in a waiver to the adult system (Puzzanchera and Robson 2014). The results from the literature on transferred juveniles may not, therefore, generalize to the larger population of juvenile offenders charged with a felony or misdemeanor who are affected by legislation that raises the age of majority for all offenders charged with a felony or misdemeanor. 


\section{RESEARCH AND METHODS}

\subsection{Data}

The data for this study were requested and received from the Research and Evaluation Division of the Chicago Police Department in early 2013. The data cover all arrests from January 1999 until February 2013. They include the following information for each arrest: the date of arrest, the most serious offense charged, and the date of birth, gender, and race of the arrestee. We exclude all arrests that lack a fingerprint identification number, a charge grade, or a birth date in the data. The remaining observations consist of 22,779 misdemeanor arrests of 16-, 17-, and 18-yearolds between the years 2009 and 2010. We use data on cases from before 2009 to provide descriptive trends for recidivism before the law went into effect.

We created a binary outcome variable indicating whether an individual was rearrested by the Chicago Police Department within 2 years of the recorded offense. We also created a second outcome variable indicating whether an individual was rearrested for a violent crime. ${ }^{1}$ Our 2-year follow-up period represents a compromise between several competing methodological considerations. First, the observed effect of a treatment can vary depending on the follow-up period, and longer follow-up periods are usually preferable. As the change in law went into effect on January 1, 2010, and our data include all arrests until the end of 2012, the longest possible follow-up period is 3 years. Second, to avoid censoring problems, all subjects must have an equal period of time to recidivate after the initial arrest. Third, a longer follow-up period disqualifies subjects from the potential analysis sample because of censoring. As a reasonable trade-off of these considerations, we use a 2-year follow-up period, which allows all arrestees in 2010 to be included in the analysis.

We also calculate the number of days until subjects are rearrested to assess whether timing varies across subgroups in our sample. An analysis of timing may provide some insight into theoretical mechanisms. For example, if pretrial detention or incarceration affects one group more than the others, we would expect to see delays in the time to rearrest.

1. Violent crimes include homicide, robbery, aggravated assault, simple assault, and sexual assault. 


\subsection{Analytic Strategy}

On January 1, 2010, Illinois raised the criminal age of majority for misdemeanor crimes from 17 to 18 . Before that date, 17-year-olds arrested for a misdemeanor were prosecuted in the adult criminal justice system. Since that date, they have been processed in the juvenile system. The law did not affect 16- or 18-year-old arrestees. To verify that the law was implemented as enacted, we graph the monthly probability of juvenile case disposition postarrest for 16-, 17-, and 18-year-olds from January 2009 until December 2010 (Figure 1). Consistent with the change in law, the probability of juvenile case disposition (that is, juvenile station adjustment, referral to juvenile court, or detention in a juvenile facility) went from 0 to nearly 1 immediately after the law was implemented, while the probabilities of juvenile case disposition for 16- and 18-year-olds remained unchanged at 1 and 0 , respectively.

We apply a DID design to pooled cross sections over time to estimate the effect of Illinois's raise-the-age legislation on recidivism in Chicago. Such DID designs have been used extensively to evaluate changes in policy that affect some but not all units subject to similar conditions (Card 1992; Gruber 2000). In our first set of DID models, we compare the change in the rearrest rate of 17-year-old arrestees (the treatment group) from 2009 to 2010 with the change in the rearrest rate of 18 -year-olds (the control group) during that period. The model is as follows:

$\Delta Y_{i}=\beta_{0}+\beta_{1}$ Age17 $_{i}+\beta_{2}$ Year2010 $_{i}+\beta_{3}$ Age17 $_{i} \times$ Year2010 $_{i}+\mu_{i}$,

where $Y_{i}$ is a 2 -year measure of rearrest for arrested suspect $i$, Age $17_{i}$ is a dummy variable indicating that the arrested suspect was 17 years old, Year2010 is a dummy variable indicating that the arrest took place in $2010, \beta_{0}$ reflects the average rearrest rate for 18 -year-olds in $2009, \beta_{i}$ captures differences between 17- and 18-year-olds before the policy change, $\beta_{2}$ captures the difference between the probability of rearrest in 2009 and 2010 for 18-year-olds, and $\beta_{3}$ is the relevant DID estimate of the effect of the law on recidivism. We estimate these models using ordinary least squares regression on the subpopulation of 17- and 18-year-olds arrested in 2009 and 2010 (Angrist and Pischke 2009).

In our second set of models, we use 16-year-olds rather than 18-yearolds as the control group. In these models, the relevant treatment group is 17 -year-olds arrested in 2010 , and $\beta_{0}$ reflects the average rearrest rate for 16-year-olds in 2009, $\beta_{1}$ captures any differences between 16 - and 17 -year-olds before the policy change, $\beta_{2}$ captures the difference between 


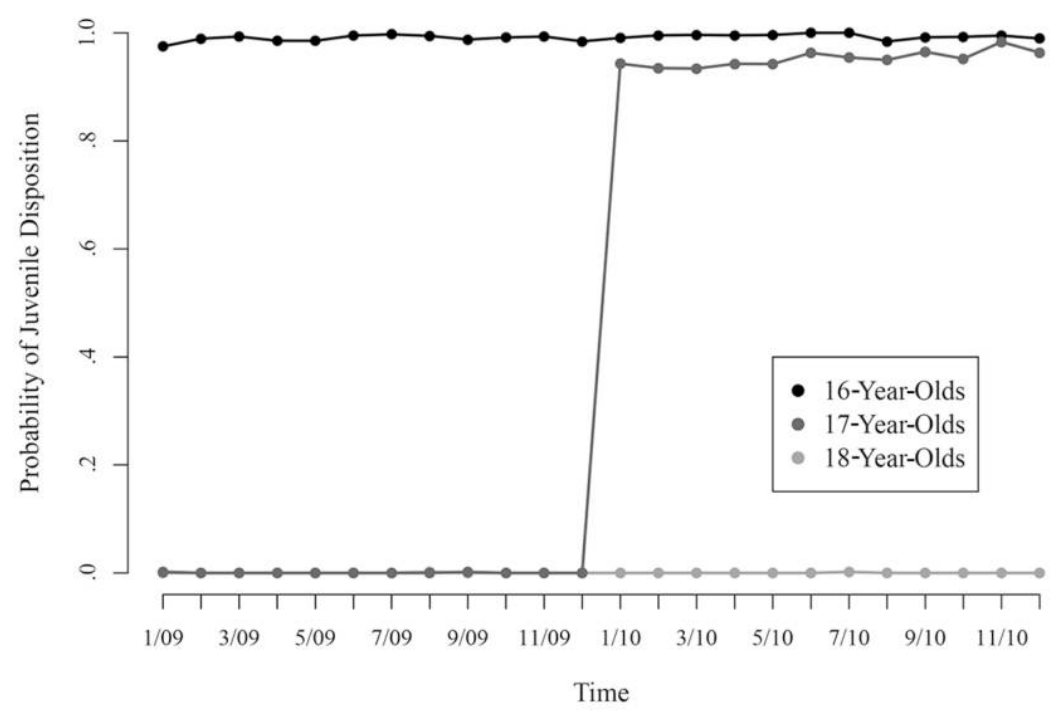

Figure 1. Probability of juvenile case disposition

the probability of rearrest in 2009 and 2010 for 16 -year-olds, and $\beta_{3}$ is the relevant DID estimate of the effect of the law on recidivism as it captures the difference between reoffending for 16- and 17-year-olds.

The primary assumption in the DID context is that of parallel trends: no nontreatment variables should change during the study period that affect the recidivism of one group differently than the other. Because of differences in developmental maturation, it is possible that differences between 17-year-olds and 16- and 18-year-olds introduce bias into the model.

We assess the plausibility of using 16- and 18-year-olds as controls for 17-year-olds in two ways. First, we check for balance on pretreatment covariates. Table 1 provides a comparison of pretreatment covariates for 17- and 18-year-olds arrested in 2009. Although there are statistically significant differences, Table 1 shows that 17 - and 18 -year-olds are relatively similar in terms of demographic characteristics and the composition of charges for which they are arrested. As a general rule of thumb, standardized mean differences of .1 or less suggest adequate balance. The standardized mean differences for nearly all covariates in Table 1 are below or just above .1. Seventeen-year-old arrestees are slightly less likely to be male and white and commit slightly more violent and property crimes. 
Table 1. Comparison of Characteristics: 17 - and 18-Year-Olds Arrested in 2009

\begin{tabular}{|c|c|c|c|c|c|c|c|}
\hline & \multicolumn{2}{|c|}{ Mean } & \multicolumn{2}{|c|}{ SD } & \multirow{2}{*}{$\begin{array}{c}\text { Mean } \\
\text { Difference }\end{array}$} & \multirow{2}{*}{$\begin{array}{c}\text { Standardized } \\
\text { Mean } \\
\text { Difference }\end{array}$} & \multirow[b]{2}{*}{$t$-Test } \\
\hline & 17 & 18 & 17 & 18 & & & \\
\hline Male & .845 & .857 & .362 & .350 & -.012 & -.034 & .060 \\
\hline White & .285 & .300 & .451 & .458 & -.015 & -.034 & .062 \\
\hline Black & .709 & .695 & .454 & .461 & .014 & .032 & .080 \\
\hline Other race & .005 & .004 & .072 & .065 & .001 & .014 & .433 \\
\hline Total priors & 4.972 & 6.140 & 6.111 & 7.185 & -1.168 & -.175 & .000 \\
\hline Property crime & .192 & .189 & .394 & .392 & .003 & .007 & .678 \\
\hline Violent crime & .200 & .157 & .400 & .364 & .043 & .113 & .000 \\
\hline Drug crime & .254 & .308 & .436 & .462 & -.054 & -.120 & .000 \\
\hline Other crime & .354 & .346 & .478 & .476 & .008 & .017 & .353 \\
\hline \multicolumn{8}{|c|}{ Recidivism within } \\
\hline 2 years & .753 & .731 & .431 & .443 & .022 & .050 & .005 \\
\hline \multicolumn{8}{|c|}{$\begin{array}{l}\text { Arrest days before } \\
\text { or after } 17 \text { th }\end{array}$} \\
\hline birthday & 183.8 & 176.6 & 105.1 & 106.1 & 7.2 & .068 & 0 \\
\hline
\end{tabular}

Note. $N=6,47917$-year-olds and 5,845 18-year-olds.

But Table 1 also shows a substantial difference in arrest history between 17- and 18-year-olds. Eighteen-year-olds tend to have, on average, one more prior arrest than 17-year-olds because they have had 1 more year of adolescence to commit crimes. The same general patterns are observed when comparing 16-year-olds with 17-year-olds (see Table A1 in the online appendix).

Second, we assess whether the recidivism of 17-year-olds follows a trend over time similar to that of 16- and 18-year-olds. Figure 2 presents the average rates of recidivism by age of juveniles arrested over time. There are a few periods when the trends diverge. There are also small differences in the level of each curve on the $Y$-axis. However, in general, the 16- and 18-year-olds tend to follow the same general trend as the 17-year-olds.

Together, the comparison of pretreatment covariates and the assessment of trends over time suggest that 16- and 18-year-olds may be appropriate control groups for 17-year-olds, but there are some nontrivial differences. To improve the comparability of the treatment and control groups, we fitted the DID models to two different subsets of the data. First, we fitted an age-limited model. When using 18-year-olds as the control group, we fitted the DID model to subjects arrested within 60 days of their 18th birthday. When using 16-year-olds as the control group, we fitted the DID model to subjects arrested within 60 days of their 17 th birth- 


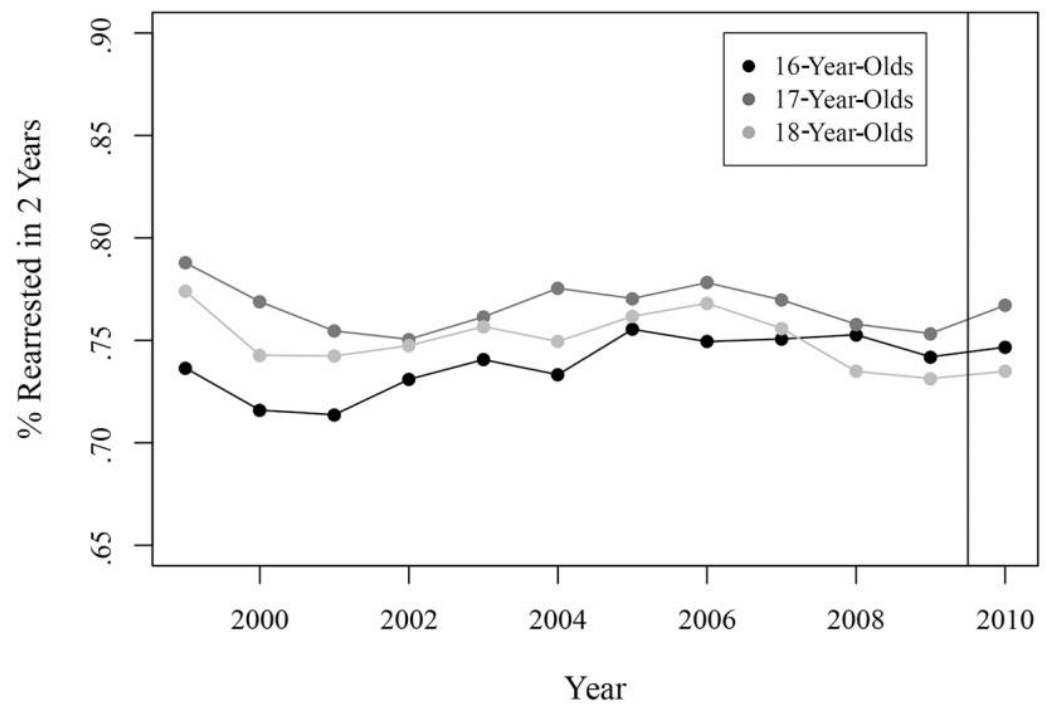

Figure 2. Average recidivism rates

day. This ensures that any two juveniles in the model are no more than 120 days apart in age. The vast majority of subjects are closer in age.

Table 2 compares the pretreatment covariates for 17- and 18-yearolds in the age-limited models and shows improved balance on most covariates. Most important, the substantial difference in criminal history observed in Table 1 virtually disappears, and the standardized mean differences are all well below .1. The results are substantively similar when comparing 17- and 16-year-olds arrested within 60 days of their 17th birthday (see Table A2 in the online appendix).

Figures 3 and 4 present the trends in recidivism for the 17- and 18-year-olds and the 17- and 16-year-olds in the age-restricted models, respectively. Figure 3 shows that the 17 - and 18 -year-olds are on the same level on the $Y$-axis and have a very similar trend over time. The divergence in trends between 2003 and 2005 is likely the result of statistical error due to a smaller sample size. The trends for the 17- and 16-yearolds in the age-restricted models also track each other (Figure 4) but perhaps less well.

We also examined the number of suspects arrested 60 days before and 60 days after their 17th or 18th birthday to test for any shifts in density that might coincide with the 2010 change in law (see Figures A1 and 
Table 2. Comparison of Characteristics: 17- and 18-Year-Olds Arrested in 2009 within 60 Days of Their 18th Birthday

\begin{tabular}{|c|c|c|c|c|c|c|c|}
\hline & \multicolumn{2}{|c|}{ Mean } & \multicolumn{2}{|c|}{ SD } & \multirow{2}{*}{$\begin{array}{c}\text { Mean } \\
\text { Difference }\end{array}$} & \multirow{2}{*}{$\begin{array}{c}\text { Standardized } \\
\text { Mean } \\
\text { Difference }\end{array}$} & \multirow[b]{2}{*}{$t$-Test } \\
\hline & 17 & 18 & 17 & 18 & & & \\
\hline Male & .840 & .851 & .367 & .356 & -.011 & -.032 & .466 \\
\hline White & .312 & .301 & .463 & .459 & .011 & .023 & .598 \\
\hline Black & .679 & .692 & .467 & .462 & -.013 & -.029 & .505 \\
\hline Other race & .009 & .006 & .092 & .075 & .003 & .034 & .430 \\
\hline Total priors & 5.885 & 6.188 & 7.372 & 7.016 & -.303 & -.042 & .333 \\
\hline Property crime & .218 & .208 & .413 & .406 & .010 & .024 & .577 \\
\hline Violent crime & .174 & .172 & .380 & .378 & .002 & .006 & .899 \\
\hline Drug crime & .247 & .276 & .431 & .447 & -.029 & -.065 & .135 \\
\hline Other crime & .360 & .344 & .480 & .475 & .016 & .035 & .426 \\
\hline \multicolumn{8}{|c|}{ Recidivism within } \\
\hline 2 years & .738 & .742 & .440 & .438 & -.004 & -.010 & .811 \\
\hline \multicolumn{8}{|c|}{$\begin{array}{l}\text { Arrest days before } \\
\text { or after } 17 \text { th }\end{array}$} \\
\hline$N$ & 1,049 & 1,056 & & & & & \\
\hline
\end{tabular}

Note. $N=1,049$ 17-year-olds and 1,056 18-year-olds.

A2 in the online appendix). We do observe a subtle shift. A stable gap in arrests between those just under 17 and those just over 17 closes after 2010. Similarly, a stable gap in arrests between those just under 18 and those just over 18 emerges after 2010. This pattern suggests that the change in law may trigger some selection processes in the decision to arrest, but they appear pseudorandom given the absence of any covariate imbalance in Tables 2 and A2. We suspect that this trend may be due to a lack of interest among a subset of officers in arresting juvenile offenders for misdemeanors or to jurisdictional differences in charging practices and standards. This shift in the number of arrestees is a cause for concern, but the near-perfect covariate balance suggests that comparable juveniles were arrested on either side of the age threshold both before and after 2010.

As a further check on the robustness of our estimates, we also fitted a time-limited model. We fitted the DID model on arrests that took place within 60 days of January 1, 2010, the date the law went into effect. Restricting the data to this 60-day window may help remove bias resulting from secular trends over time. However, it is also possible that the time-restricted subsample biases the model downward if the Chicago Po- 


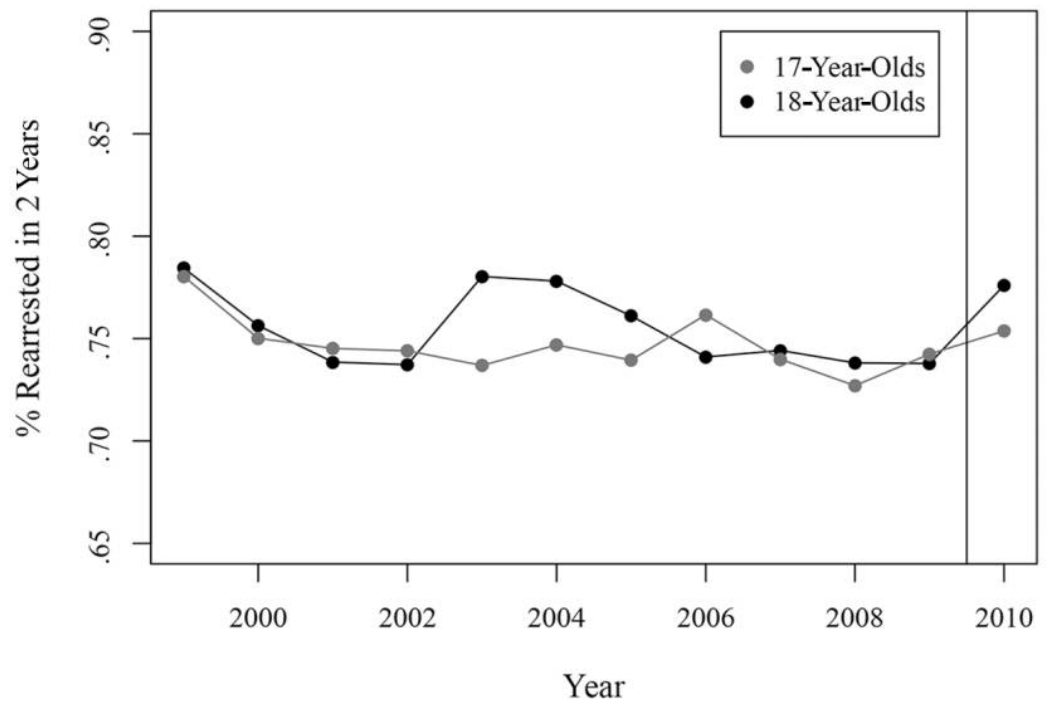

Figure 3. Recidivism of 17 - and 18-year-olds within 60 days of their 18th birthday

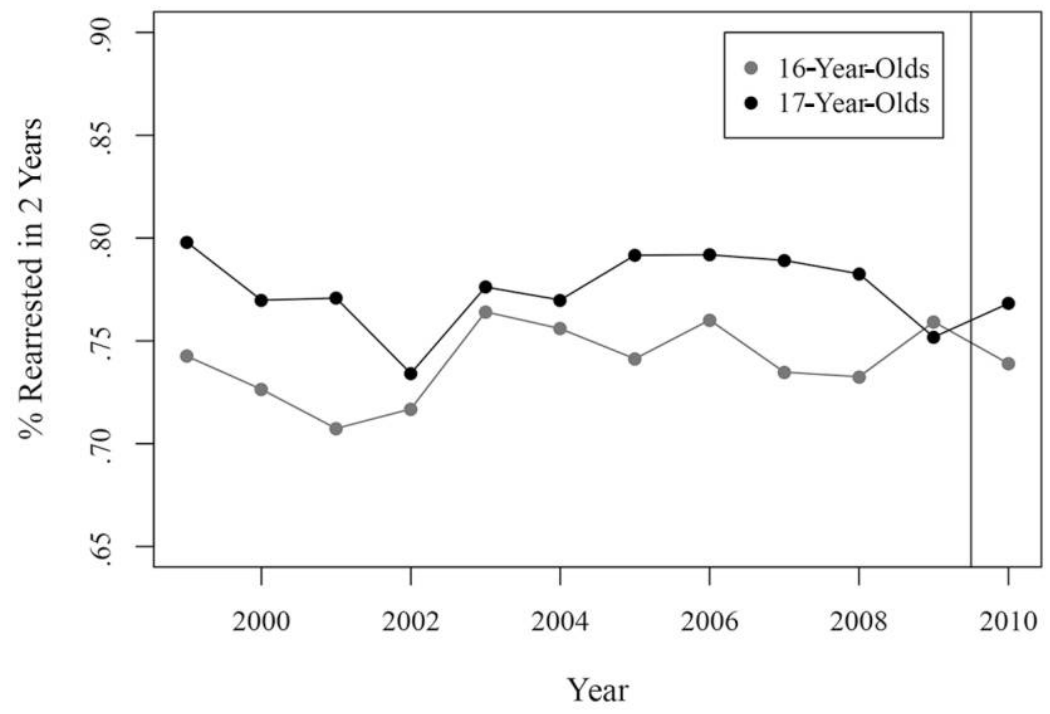

Figure 4. Recidivism of 16 - and 17 -year-olds within 60 days of their 17 th birthday 
Table 3. Models for Any Rearrest, with 18-Year-Olds as Controls

\begin{tabular}{|c|c|c|c|c|c|c|}
\hline \multirow[b]{2}{*}{ Variable } & \multicolumn{2}{|c|}{$\begin{array}{c}\text { Full } \\
(N=23,576)\end{array}$} & \multicolumn{2}{|c|}{$\begin{array}{l}\text { Age Limited } \\
(N=4,009)\end{array}$} & \multicolumn{2}{|c|}{$\begin{array}{l}\text { Time Limited } \\
(N=3,566)\end{array}$} \\
\hline & $b$ & $P$ & $b$ & $P$ & $b$ & $P$ \\
\hline Intercept & $\begin{array}{l}.731 * * \\
(.006) \\
{[.743]}\end{array}$ & 0 & $\begin{array}{l}.742 \% * \\
(.013) \\
{[.768]}\end{array}$ & 0 & $\begin{array}{l}.712 * * \\
(.016) \\
{[.743]}\end{array}$ & 0 \\
\hline Age17 & $\begin{array}{l}.022^{* *} \\
(.008) \\
{[.037]}\end{array}$ & .005 & $\begin{array}{l}-.005 \\
(.019) \\
{[.032]}\end{array}$ & .808 & $\begin{array}{l}.046^{*} \\
(.021) \\
{[.088]}\end{array}$ & .03 \\
\hline Year2010 & $\begin{array}{l}.003 \\
(.008) \\
{[.019]}\end{array}$ & .668 & $\begin{array}{l}.011 \\
(.019) \\
{[.049]}\end{array}$ & .553 & $\begin{array}{l}.021 \\
(.022) \\
{[.064]}\end{array}$ & .324 \\
\hline Age17 × Year2010 & $\begin{array}{l}.010 \\
(.011) \\
{[.033]}\end{array}$ & .366 & $\begin{array}{c}.027 \\
(.027) \\
{[.081]}\end{array}$ & .325 & $\begin{array}{c}-.044 \\
(.030) \\
{[.014]}\end{array}$ & .138 \\
\hline
\end{tabular}

Note. Standard errors are in parentheses. Values in brackets represent the upper bound of the 95 percent confidence interval for the coefficient.

$* P<.05$.

$\because P<.01$.

lice Department did not fully implement the law in the first 60 days of 2010.

\section{RESULTS}

Table 3 presents the results of the models that use 18-year-olds as controls for 17-year-olds. The full model includes all 17- and 18-year-olds. The primary finding of interest is the interaction of Age17 and Year2010, which estimates the effect of the change in law. The full model shows that the effect of the law is essentially 0 and statistically insignificant. For the results of the age-limited model, with just those subjects arrested within 60 days of their 18th birthday, the coefficient is slightly larger, but it remains small and statistically insignificant. For the time-limited model, with 17- and 18-year-olds arrested within 60 days of January 1, 2010, the day the law went into effect, the coefficient of interest is negative and slightly larger than the estimates in the other models, but it remains small and statistically insignificant.

Table 4 presents substantively similar results for our models that use 16-year-olds as controls for 17-year-olds. The estimated coefficients are 
Table 4. Models for Any Rearrest, with 16-Year-0lds as Controls

\begin{tabular}{|c|c|c|c|c|c|c|}
\hline \multirow[b]{2}{*}{ Variable } & \multicolumn{2}{|c|}{$\begin{array}{c}\text { Full } \\
(N=21,943)\end{array}$} & \multicolumn{2}{|c|}{$\begin{array}{l}\text { Age Limited } \\
(N=3,653)\end{array}$} & \multicolumn{2}{|c|}{$\begin{array}{l}\text { Time Limited } \\
(N=3,609)\end{array}$} \\
\hline & $b$ & $P$ & $b$ & $P$ & $b$ & $P$ \\
\hline Intercept & $\begin{array}{l}.742 * * \\
(.006) \\
{[.754]}\end{array}$ & 0 & $\begin{array}{l}.759 * * \\
(.015) \\
{[.788]}\end{array}$ & 0 & $\begin{array}{l}.739 * * \\
(.015) \\
{[.769]}\end{array}$ & 0 \\
\hline Age17 & $\begin{array}{l}.011 \\
(.008) \\
{[.027]}\end{array}$ & .157 & $\begin{array}{l}-.007 \\
(.020) \\
{[.031]}\end{array}$ & .706 & $\begin{array}{l}.019 \\
(.021) \\
{[.06]}\end{array}$ & .361 \\
\hline Year2010 & $\begin{array}{c}.005 \\
(.009) \\
{[.022]}\end{array}$ & .585 & $\begin{array}{l}-.02 \\
(.021) \\
{[.021]}\end{array}$ & .334 & $\begin{array}{c}-.018 \\
(.021) \\
{[.024]}\end{array}$ & .392 \\
\hline Age17 × Year2010 & $\begin{array}{c}.009 \\
(.012) \\
{[.032]}\end{array}$ & .442 & $\begin{array}{c}.037 \\
(.029) \\
{[.093]}\end{array}$ & .201 & $\begin{array}{l}-.004 \\
(.029) \\
{[.053]}\end{array}$ & .885 \\
\hline
\end{tabular}

Note. Standard errors are in parentheses. Values in brackets represent the upper bound of the 95 percent confidence interval for the coefficient.

$* P<.01$.

small and statistically insignificant, with all but the age-limited model between .01 and .00 in magnitude. Reestimating each of the models in Tables 3 and 4 with covariates produces nearly identical results (see Tables A5 and A6 in the online appendix).

Given the high rates of rearrest observed in our sample, we also examine the timing of rearrest using Cox proportional hazard models with the same variables as in our DID models. Figure 5 shows the probability of survival for 17-year-olds arrested in 2010 along with values for each of the three comparison groups. Comparing 16-year-olds with 17-year-olds and 17-year-olds with 18-year-olds in our age-limited models (see Table A7 in the online appendix), we find that there are no statistically significant differences in the timing of recidivism.

We next examine whether our model estimates of rearrest vary by the length of the follow-up period, starting with a 6-month follow-up and extending it to a full 24-month follow-up. Tables 5 and 6, which display the DID estimators for these models, provide little evidence that the follow-up period affects the results. All of the coefficients are statistically indistinguishable from 0 . The models that use 18-year-olds as controls have similar coefficients for the 12-, 18-, and 24-month follow-up periods, although the coefficients for the 6-month follow-up period differ somewhat. The models that use 16-year-olds as controls provide much 


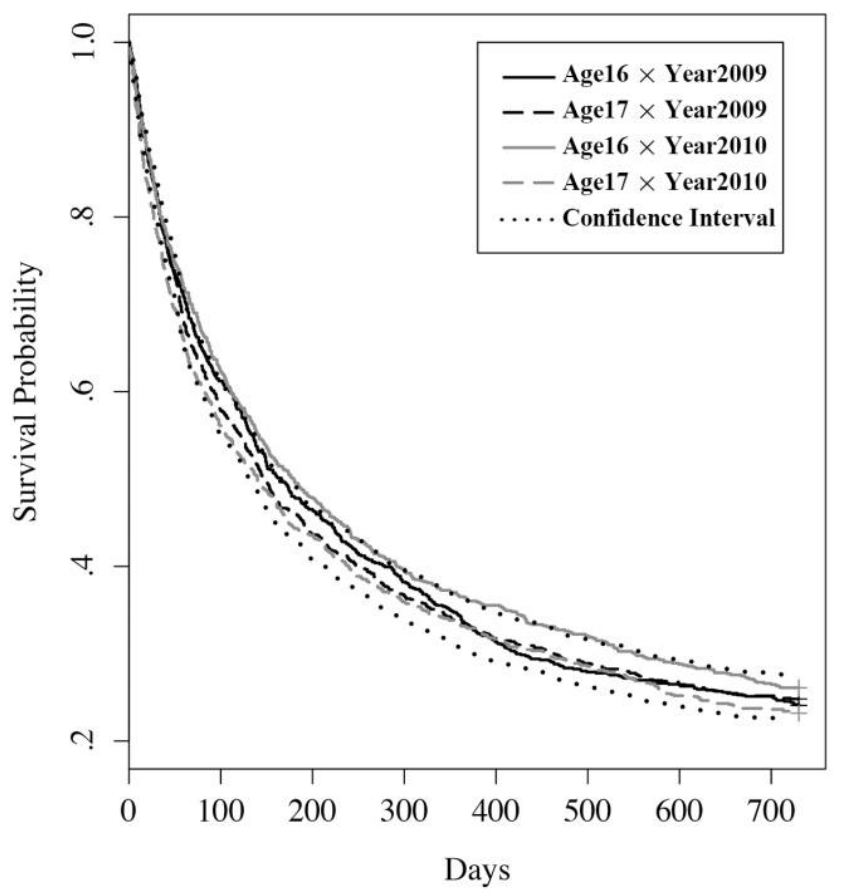

Figure 5. Time until rearrest: 17 - and 16 -year-olds within 60 days of their 17 th birthday

less evidence that the follow-up period affects the results, particularly for the age- and time-limited models, which provide the cleanest counterfactuals.

In addition, we examined the average number of arrests for 16-, 17-, and 18-year-olds to see if the volume of age-specific reoffending was noticeably different after the change in law. Reported in Table A8 in the online appendix, these average rates of rearrest suggest that the age-specific incidence of arrest was stable.

As a further sensitivity analysis, we reestimate our models to examine the effect of raising the age of majority on rearrests for violent crimes. Table 7 reports the results using 18 -year-olds as controls. In the full model, the coefficient is .00 and statistically insignificant. The age- and time-limited models estimate slightly different coefficients, but both are between .01 and -.01 and statistically insignificant. For the comparison with 16- and 17-year-olds, reported in Table 8, the estimate for the full 
Table 5. Rearrests with Alternative Follow-up Periods, with 18-Year-Olds as Controls

\begin{tabular}{|c|c|c|c|c|c|c|}
\hline \multirow[b]{2}{*}{ Period } & \multicolumn{2}{|c|}{$\begin{array}{c}\text { Full } \\
(N=23,576)\end{array}$} & \multicolumn{2}{|c|}{$\begin{array}{l}\text { Age Limited } \\
(N=4,009)\end{array}$} & \multicolumn{2}{|c|}{$\begin{array}{l}\text { Time Limited } \\
(N=3,566)\end{array}$} \\
\hline & $b$ & $P$ & $b$ & $P$ & $b$ & $P$ \\
\hline 6 Months & $\begin{array}{c}-.022 \\
(.013) \\
{[.003]}\end{array}$ & .085 & $\begin{array}{c}-.047 \\
(.032) \\
{[.016]}\end{array}$ & .139 & $\begin{array}{l}-.010 \\
(.034) \\
{[.057]}\end{array}$ & .771 \\
\hline 12 Months & $\begin{array}{c}-.001 \\
(.012) \\
{[.022]}\end{array}$ & .956 & $\begin{array}{l}.001 \\
(.030) \\
{[.060]}\end{array}$ & .962 & $\begin{array}{l}-.041 \\
(.032) \\
{[.022]}\end{array}$ & .204 \\
\hline 18 Months & $\begin{array}{c}.004 \\
(.012) \\
{[.028]}\end{array}$ & .756 & $\begin{array}{l}.007 \\
(.029) \\
{[.064]}\end{array}$ & .809 & $\begin{array}{l}-.046 \\
(.031) \\
{[.015]}\end{array}$ & .14 \\
\hline 24 Months & $\begin{array}{l}.010 \\
(.011) \\
{[.032]}\end{array}$ & .366 & $\begin{array}{l}.020 \\
(.027) \\
{[.073]}\end{array}$ & .325 & $\begin{array}{l}-.044 \\
(.030) \\
{[.015]}\end{array}$ & .138 \\
\hline
\end{tabular}

Note. Standard errors are in parentheses. Values in brackets represent the upper bound of the 95 percent confidence interval for the coefficient.

Table 6. Rearrests with Alternative Follow-up Periods, with 16-Year-0lds as Controls

\begin{tabular}{|c|c|c|c|c|c|c|}
\hline \multirow[b]{2}{*}{ Period } & \multicolumn{2}{|c|}{$\begin{array}{c}\text { Full } \\
(N=21,943)\end{array}$} & \multicolumn{2}{|c|}{$\begin{array}{l}\text { Age Limited } \\
(N=3,653)\end{array}$} & \multicolumn{2}{|c|}{$\begin{array}{l}\text { Time Limited } \\
(N=3,609)\end{array}$} \\
\hline & $b$ & $P$ & $b$ & $P$ & $b$ & $P$ \\
\hline 6 Months & $\begin{array}{c}-.012 \\
(.014) \\
{[.015]}\end{array}$ & .369 & $\begin{array}{l}.032 \\
(.033) \\
{[.097]}\end{array}$ & .336 & $\begin{array}{l}.000 \\
(.033) \\
{[.066]}\end{array}$ & .993 \\
\hline 12 Months & $\begin{array}{c}-.002 \\
(.013) \\
{[.023]}\end{array}$ & .847 & $\begin{array}{c}.031 \\
(.032) \\
{[.094]}\end{array}$ & .319 & $\begin{array}{l}-.005 \\
(.032) \\
{[.058]}\end{array}$ & .882 \\
\hline 18 Months & $\begin{array}{c}.005 \\
(.012) \\
{[.029]}\end{array}$ & .654 & $\begin{array}{l}.036 \\
(.030) \\
{[.095]}\end{array}$ & .225 & $\begin{array}{c}.000 \\
(.031) \\
{[.062]}\end{array}$ & .991 \\
\hline 24 Months & $\begin{array}{c}.009 \\
(.012) \\
{[.033]}\end{array}$ & .442 & $\begin{array}{c}.037 \\
(.029) \\
{[.094]}\end{array}$ & .201 & $\begin{array}{c}-.004 \\
(.029) \\
{[.053]}\end{array}$ & .885 \\
\hline
\end{tabular}

Note. Standard errors are in parentheses. Values in brackets represent the upper bound of the 95 percent confidence interval for the coefficient.

model is .01 and statistically insignificant. The estimates in both the ageand time-limited models are larger in magnitude, but they remain statistically insignificant. These models provide little evidence of an effect and, if anything, suggest that the change in law resulted in a slight increase in 
Table 7. Rearrests for Violent Crimes, with 18-Year-0lds as Controls

\begin{tabular}{|c|c|c|c|c|c|c|}
\hline \multirow[b]{2}{*}{ Variable } & \multicolumn{2}{|c|}{$\begin{array}{c}\text { Full } \\
(N=23,576)\end{array}$} & \multicolumn{2}{|c|}{$\begin{array}{l}\text { Age Limited } \\
(N=4,009)\end{array}$} & \multicolumn{2}{|c|}{$\begin{array}{l}\text { Time Limited } \\
(N=3,566)\end{array}$} \\
\hline & $b$ & $P$ & $b$ & $P$ & $b$ & $P$ \\
\hline Intercept & $\begin{array}{l}.246^{* *} \\
(.006) \\
{[.257]}\end{array}$ & .000 & $\begin{array}{l}.253^{* *} \\
(.014) \\
{[.28]}\end{array}$ & .000 & $\begin{array}{l}.253^{* *} \\
(.016) \\
{[.284]}\end{array}$ & .000 \\
\hline Age17 & $\begin{array}{l}.054 * * \\
(.008) \\
{[.07]}\end{array}$ & .000 & $\begin{array}{l}.04 \% \\
(.020) \\
{[.078]}\end{array}$ & .043 & $\begin{array}{l}.046^{*} \\
(.022) \\
{[.089]}\end{array}$ & .033 \\
\hline Year2010 & $\begin{array}{l}.019^{*} \\
(.008) \\
{[.036]}\end{array}$ & .021 & $\begin{array}{l}.022 \\
(.020) \\
{[.061]}\end{array}$ & .264 & $\begin{array}{l}.011 \\
(.022) \\
{[.054]}\end{array}$ & .629 \\
\hline Age17 × Year2010 & $\begin{array}{c}.000 \\
(.012) \\
{[.023]}\end{array}$ & .972 & $\begin{array}{l}.005 \\
(.029) \\
{[.061]}\end{array}$ & .848 & $\begin{array}{l}-.006 \\
(.030) \\
{[.054]}\end{array}$ & .851 \\
\hline
\end{tabular}

Note. Standard errors are in parentheses. Values in brackets represent the upper bound of the 95 percent confidence interval for the coefficient.

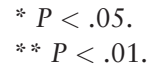

Table 8. Rearrests for Violent Crimes, with 16 -Year-0lds as Controls

\begin{tabular}{|c|c|c|c|c|c|c|}
\hline \multirow[b]{2}{*}{ Variable } & \multicolumn{2}{|c|}{$\begin{array}{c}\text { Full } \\
(N=21,943)\end{array}$} & \multicolumn{2}{|c|}{$\begin{array}{l}\text { Age Limited } \\
(N=3,653)\end{array}$} & \multicolumn{2}{|c|}{$\begin{array}{l}\text { Time Limited } \\
(N=3,609)\end{array}$} \\
\hline & $b$ & $P$ & $b$ & $P$ & $b$ & $P$ \\
\hline Intercept & $\begin{array}{l}.364^{* * *} \\
(.007) \\
{[.377]}\end{array}$ & .000 & $\begin{array}{l}.351^{* * *} \\
(.016) \\
{[.382]}\end{array}$ & .000 & $\begin{array}{l}.384^{* * *} \\
(.016) \\
{[.416]}\end{array}$ & .000 \\
\hline Age17 & $\begin{array}{l}-.064 * * \\
(.009) \\
{[-.047]}\end{array}$ & .000 & $\begin{array}{c}-.053^{*} \\
(.022) \\
{[-.011]}\end{array}$ & .013 & $\begin{array}{c}-.085^{* *} \\
(.022) \\
{[-.042]}\end{array}$ & .000 \\
\hline Year2010 & $\begin{array}{l}.005 \\
(.009) \\
{[.023]}\end{array}$ & .623 & $\begin{array}{l}.01 \\
(.023) \\
{[.055]}\end{array}$ & .678 & $\begin{array}{c}-.052 \% \\
(.023) \\
{[-.007]}\end{array}$ & .023 \\
\hline Age17 × Year2010 & $\begin{array}{l}.014 \\
(.013) \\
{[.039]}\end{array}$ & .266 & $\begin{array}{l}.055 \\
(.031) \\
{[.117]}\end{array}$ & .081 & $\begin{array}{c}.057 \\
(.031) \\
{[.118]}\end{array}$ & .07 \\
\hline
\end{tabular}

Note. Standard errors are in parentheses. Values in brackets represent the upper bound of the 95 percent confidence interval for the coefficient.

$$
\begin{aligned}
& * P<.05 . \\
& * P<.01 .
\end{aligned}
$$


rearrests for violent crimes if we apply a less stringent standard of statistical significance.

Taken together, our results provide little evidence of a change in recidivism after the law went into effect. The most plausible explanation is that the law had no effect. But it is also possible that the law had multiple countervailing effects of similar magnitude that mask each other. For example, processing 17-year-old offenders for misdemeanors in the juvenile system may decrease deterrence while increasing incapacitation. To test this hypothesis, we refit our models to subsets of the sample with different levels of criminal history and instant offenses. The rate of pretrial detention is very low for both juvenile and adult arrestees for misdemeanors who have no criminal history, but we suspect that pretrial detention rates may differ more dramatically for juveniles and adults with longer criminal histories. In Tables 9 and 10, we refit our models to groups with different levels of criminal history. While the estimates are less precise, they provide little evidence of treatment effect heterogeneity across criminal histories. We found similar results for models estimated across instant offense categories (see Tables A9 and A10 in the online appendix). This finding, combined with the similar timing of rearrest in our hazard models, reinforces our conclusion that the law had no effect on recidivism.

\section{DISCUSSION AND CONCLUSION}

After an extended period of contraction at the end of the 20th century, a number of states expanded the jurisdiction of the juvenile court by raising the age of majority to 18 . Proponents argue that these legislative changes reduce juvenile recidivism, and they cite the continued decline in juvenile crime as evidence that they do not harm public safety. Critics, in contrast, voice concerns about the cost of juvenile processing and the risk of increased crime. To date, no empirical study has systematically tested whether raising the age of majority has an effect on juvenile offending.

The present study examines the effect on recidivism of a 2010 Illinois law that raised the age of majority for misdemeanor crimes from 17 to 18 . Using a DID design, we compare the change in recidivism among 17-year-old arrestees before and after 2010 with the change in recidivism among 16- and 18-year-old arrestees (who were unaffected by the law change) during that period. Our results consistently show no statistically significant effect.

Some of our estimated effects are sufficiently imprecise to leave room 
Table 9. Rearrests by Criminal History, with 18 -Year-Olds as Controls

\begin{tabular}{|c|c|c|c|c|c|c|c|c|}
\hline \multirow[b]{2}{*}{ Variable } & \multicolumn{2}{|c|}{$\begin{array}{c}\text { All } \\
(N=4,009)\end{array}$} & \multicolumn{2}{|c|}{$\begin{array}{l}\text { No Priors } \\
(N=788)\end{array}$} & \multicolumn{2}{|c|}{$\begin{array}{l}1-2 \text { Priors } \\
(N=897)\end{array}$} & \multicolumn{2}{|c|}{$\begin{array}{l}3-10 \text { Priors } \\
(N=1,551)\end{array}$} \\
\hline & $b$ & $P$ & $b$ & $P$ & $b$ & $P$ & $b$ & $P$ \\
\hline Intercept & $\begin{array}{l}.742^{* * *} \\
(.013) \\
{[.768]}\end{array}$ & .000 & $\begin{array}{l}.311^{* *} \\
(.033) \\
{[.376]}\end{array}$ & .000 & $\begin{array}{l}.687^{* * *} \\
(.032) \\
{[.750]}\end{array}$ & .000 & $\begin{array}{l}.883 * * \\
(.015) \\
{[.913]}\end{array}$ & .000 \\
\hline Age17 & $\begin{array}{l}-.005 \\
(.019) \\
{[.032]}\end{array}$ & .808 & $\begin{array}{l}.058 \\
(.046) \\
{[.149]}\end{array}$ & .210 & $\begin{array}{l}-.052 \\
(.045) \\
{[.035]}\end{array}$ & .242 & $\begin{array}{l}.01 \\
(.022) \\
{[.053]}\end{array}$ & .633 \\
\hline Year2010 & $\begin{array}{l}.011 \\
(.019) \\
{[.049]}\end{array}$ & .553 & $\begin{array}{l}.052 \\
(.048) \\
{[.147]}\end{array}$ & .279 & $\begin{array}{l}-.031 \\
(.045) \\
{[.056]}\end{array}$ & .485 & $\begin{array}{l}.018 \\
(.022) \\
{[.061]}\end{array}$ & .415 \\
\hline Age17 × Year2010 & $\begin{array}{l}.027 \\
(.027) \\
{[.081]}\end{array}$ & .325 & $\begin{array}{c}.039 \\
(.069) \\
{[.175]}\end{array}$ & .569 & $\begin{array}{c}.054 \\
(.064) \\
{[.178]}\end{array}$ & .400 & $\begin{array}{l}-.017 \\
(.032) \\
{[.045]}\end{array}$ & .585 \\
\hline
\end{tabular}

Note. Standard errors are in parentheses. Values in brackets represent the upper bound of the 95 percent confidence interval for the coefficient.

$* P<.01$.

Table 10. Rearrests by Criminal History, with 16-Year-0lds as Controls

\begin{tabular}{|c|c|c|c|c|c|c|c|c|}
\hline \multirow[b]{2}{*}{ Variable } & \multicolumn{2}{|c|}{$\begin{array}{c}\text { All } \\
(N=3,653)\end{array}$} & \multicolumn{2}{|c|}{$\begin{array}{l}\text { No Priors } \\
(N=893)\end{array}$} & \multicolumn{2}{|c|}{$\begin{array}{l}1-2 \text { Priors } \\
(N=951)\end{array}$} & \multicolumn{2}{|c|}{$\begin{array}{l}3-10 \text { Priors } \\
(N=1,397)\end{array}$} \\
\hline & $b$ & $P$ & $b$ & $P$ & $b$ & $P$ & $b$ & $P$ \\
\hline Intercept & $\begin{array}{l}.759 * * \\
(.015) \\
{[.788]}\end{array}$ & .000 & $\begin{array}{l}.447^{* *} \\
(.033) \\
{[.512]}\end{array}$ & .000 & $\begin{array}{l}.727 * * \\
(.032) \\
{[.789]}\end{array}$ & .000 & $\begin{array}{l}.93 * * \\
(.015) \\
{[.959]}\end{array}$ & .000 \\
\hline Age17 & $\begin{array}{l}-.007 \\
(.020) \\
{[.031]}\end{array}$ & .706 & $\begin{array}{l}.013 \\
(.045) \\
{[.102]}\end{array}$ & .776 & $\begin{array}{l}-.016 \\
(.041) \\
{[.064]}\end{array}$ & .692 & $\begin{array}{l}-.016 \\
(.020) \\
{[.023]}\end{array}$ & .418 \\
\hline Year2010 & $\begin{array}{l}-.02 \\
(.021) \\
{[.021]}\end{array}$ & .334 & $\begin{array}{l}-.004 \\
(.049) \\
{[.092]}\end{array}$ & .932 & $\begin{array}{l}-.057 \\
(.044) \\
{[.028]}\end{array}$ & .188 & $\begin{array}{l}-.014 \\
(.022) \\
{[.029]}\end{array}$ & .525 \\
\hline Age17 × Year 2010 & $\begin{array}{c}.037 \\
(.029) \\
{[.093]}\end{array}$ & .201 & $\begin{array}{l}-.012 \\
(.067) \\
{[.12]}\end{array}$ & .862 & $\begin{array}{l}.07 \\
(.060) \\
{[.187]}\end{array}$ & .242 & $\begin{array}{l}.011 \\
(.030) \\
{[.069]}\end{array}$ & .711 \\
\hline
\end{tabular}

Note. Standard errors are in parentheses. Values in brackets represent the upper bound of the 95 percent confidence interval for the coefficient.

$* P<.01$.

for a change in recidivism in the high single-digit range, which is still below the double-digit estimates commonly cited in the raise-the-age debate (for example, Deitch, Breeden, and Weingarten 2012; Henrichson and Levshin 2011; Roman 2006). But several elements of our findings 
suggest that the best interpretation is that the law had little or no effect. First, across a wide range of specifications, the estimated effects are near 0 , which gives greater weight to the conclusion of no effect. Second, most of our estimates are positive, particularly in our preferred age-restricted models. If anything, we suspect that the change in law would bias our estimates upward by discouraging officers from arresting 17-year-olds for less serious offenses, making them subject to the juvenile system and, as a result, producing a pool of arrested 17-year-olds with more serious criminal histories. This would mean that the true effects are even closer to 0 than our estimates imply.

Our findings support at least two theoretical interpretations. First, it is possible that raising the age of majority has little effect on the recidivism of older juveniles and those with less serious offenses in the short term but does affect their recidivism later. The effect of the law may, for example, be delayed until offenders enter the workforce and fare better on the job market because their offenses are not in publicly available criminal records. While this is certainly possible, we observe recidivism over 2 years, which provides time for the 16-, 17-, and 18-year-old subjects to enter the job market. Still, a longer follow-up period of 3 or 4 years would help resolve this question.

Second, raising the age of majority may simply have little effect on recidivism for older juveniles and those with less serious offenses. One possible explanation is that the rehabilitative services provided in the juvenile system and the more punitive treatment in the adult system have little effect on recidivism. Another explanation is that the offenders in our sample received similar rehabilitative services and punishment in the juvenile and adult systems. Indeed, scholars have found mixed evidence on the relative severity of punishment in the juvenile and adult systems (Fagan 1996; Kurlychek and Johnson 2004; Lemmon et al. 2005), which leads some to conclude that these two systems differ more in their procedural elements than in their substantive effects (Feld 1999). It is particularly plausible that the subjects in our sample-older adolescents who commit less serious crimes-receive similar treatment in the juvenile and adult systems. However, to fully resolve these theoretical issues, additional research with detailed data on diversion and treatment programs in the juvenile and adult systems is needed.

Our results are consistent with and reinforce previous evaluations of legislative changes to the jurisdiction of the juvenile court. This work, which has been largely unmentioned during recent policy debates on 
raise-the-age legislation, finds little consistent evidence that changing the jurisdiction of the juvenile court affects the aggregate offending rate of all juveniles - an unsurprising finding given that most juveniles are probably unaware of such legislation. As noted earlier, if raise-the-age legislation has any effect on juvenile offending, there are strong theoretical reasons to expect it to be larger for the subset of juveniles who are arrested and processed (and who thus experience firsthand the effects of the legislation). Juvenile arrests require parental notification, while adult arrests do not. Juvenile arrests are less likely to involve temporary detention and more likely to lead to community-based intervention. Juvenile arrest and adjudication records are sealed by default, while adult records of arrest and adjudication are a matter of public record (Illinois Juvenile Justice Commission 2013). And yet our findings provide little evidence of a change in offending, even for juveniles who are arrested. This may result from the fact that most misdemeanor arrestees-whether they are processed in the juvenile or adult system-are likely to be released within hours of arrest and to receive diversion or community supervision rather than prison time (Cook County Juvenile Court 2010). Whether misdemeanor and juvenile courts have more in common with each other than felony and juvenile courts do, the fast failure of so many subjects in our sample suggests that whether misdemeanor arrestees are processed in the juvenile or adult system makes little difference for recidivism.

At first glance, our results are harder to reconcile with the literature on juvenile transfer, which has repeatedly found higher rates of recidivism among juveniles transferred to the adult system-a finding that has served as the empirical basis for claims that raising the age of majority lowers juvenile recidivism rates. We offer several potential explanations. First, the studies in this literature focus on serious felonies, which are relatively rare among juveniles. Our analysis focuses on misdemeanor offenders, who account for the vast majority of juvenile offenders. Moving these offenders with less serious crimes into or out of the juvenile system may not have the same effect on recidivism. Second, the transfer literature focuses on the effects of processing individual offenders in one system or the other. It is possible that a legislative enactment that moves thousands of juveniles from one system to the other all at once has a different effect. Finally, consistent with our findings, some recent studies find little evidence of an effect even for juveniles with more serious offenses (Lee and McCrary 2009; Hjalmarsson 2009). It is possible that these studies pro- 
vide a stronger estimate of the effect of processing juveniles as adults by avoiding selection problems.

The present study is subject to several important limitations. First, our analysis focuses on one city, which suggests the need for broader analyses in Illinois and elsewhere. Jurisdictions with greater treatment differentials between their juvenile and adult justice systems may experience a larger effect from raise-the-age legislation. Second, our analysis focuses on recidivism because public safety plays a central role in the national policy debate on the age of majority. Our study, therefore, leaves open many questions about the effect of raising the age of majority on other life-course outcomes such as employment and health. Third, the present investigation examines only misdemeanor offenders. We are therefore unable to draw conclusions about the effect of raising the age of majority on felony offenders. Future research may extend our work to felonies by examining other legislative changes. In 2014, for example, Illinois raised the age of majority for felonies from 17 to 18 . Connecticut offers another natural experiment, as it raised the age of majority for all crimes from 16 to 17 in 2010 and then from 17 to 18 in 2012.

Finally, our study lacks data on sentences received by offenders in our sample. This is a common problem in the literature (Bishop et al. 1996; Lee and McCrary 2009), at least partly because juvenile court data are difficult to access. Such data would provide only limited value to our analysis anyway. Because sentencing in juvenile court is indeterminate, sentencing data would provide little information about the length of time subjects spend behind bars.

In concluding, we note that our preferred interpretation of our analysis-that raising the age of majority has no effect on criminal recidivism, at least for lower-level offenders-helps resolve a key empirical question at the heart of the national debate on the age of majority. Yet our findings cannot fully resolve the normative question of whether states should raise the age of majority. Even if there is no effect on recidivism, we suspect that raising the age of majority results in benefits for other important life-course outcomes related to employment, health, life satisfaction, and victimization. And processing adolescents in the juvenile system may be fairer if adolescents are less culpable than adults for their crimes.

The wisdom of raising the age of majority may hinge on the values and financial resources of each state contemplating such a change. Since raising the age of majority for misdemeanors appears to pose little threat to public safety, states that value retaining adolescents in the juvenile jus- 
tice system should continue or begin doing so. Similarly, since raising the age of majority is unlikely to increase crime rates, states that do not value the approach of the juvenile justice system or do not have the requisite resources may retain or lower their current ages of majority for misdemeanors without adversely affecting juvenile crime, as Rhode Island did when it temporarily lowered its age of majority in pursuit of cost savings.

For policy makers seeking reductions in juvenile crime, it may prove useful to consider other policy alternatives that have a greater chance of reducing recidivism. These initiatives include cognitive behavioral therapy in juvenile justice settings (Heller et al. 2011; Landenberger and Lipsey 2005) and a regime of swift, certain, and fair sanctions (Hawken and Kleiman 2009; Bonnie et al. 2013). The latter has shown success among adults and is currently being tested in the juvenile system.

\section{REFERENCES}

Amelinckx, Andrew, and Lisa Redmond. 2013. New Massachusetts Law Places 17-Year-Olds in Juvenile Courts. Berkshire Eagle, October 6. http://www .berkshireeagle.com/news/ci_24249935/new-massachusetts-law-places-17 -year-olds-juvenile.

Angrist, Joshua D., and Jörn-Steffen Pischke. 2009. Mostly Harmless Econometrics: An Empiricist's Companion. Princeton, NJ: Princeton University Press.

Backus, Lisa. 2011. Does Allowing Younger Offenders to Be Tried as Juveniles Help Them or Enable Their Criminal Behavior? New Britain Herald, June 5. http://www.centralctcommunications.com/newbritainherald/news/article_ d7141cbb-a878-5e03-a694-ce5432741f3c.html.

Birckhead, Tamar R. 2008. North Carolina, Juvenile Court Jurisdiction, and the Resistance to Reform. North Carolina Law Review 86:1443-1500.

Bishop, Donna M. 2000. Juvenile Offenders in the Adult Criminal Justice System. Crime and Iustice 27:81-167.

Bishop, Donna M., Charles E. Frazier, Lonn Lanza-Kaduce, and Lawrence Winner. 1996. The Transfer of Juveniles to Criminal Court: Does It Make a Difference? Crime and Delinauency 42:171-91.

Bonnie, Richard J., Robert L. Johnson, Betty M. Chemers, and Julie Schuck. 2013. Reforming Juvenile Justice: A Developmental Approach. Washington, DC: National Academies Press.

Brown, Sarah Alice. 2012. Trends in Juvenile Justice State Legislation: 20012011. National Conference of State Legislatures, Denver. http://www.ncsl.org/ documents/cj/trendsinjuvenilejustice.pdf.

Byrd, Shelia. 2008. Lawmakers Seek to Change Laws. Mississippi Press, Novem- 
ber 10 .

Card, David. 1992. Do Minimum Wages Reduce Employment? A Case Study of California, 1987-89. Industrial and Labor Relations Review 46:38-54.

Cauffman, Elizabeth. 2012. Aligning Justice System Processing with Developmental Science. Criminology and Public Policy 11:751-58.

Chicago Sun-Times. 2013. Raise Age for Charging Youths as Adults. March 25.

Cook, Philip J., and John H. Laub. 2002. After the Epidemic: Recent Trends in Youth Violence in the United States. Crime and Iustice 29:1-37.

Cook County Juvenile Court. 2010. Juvenile Justice in Cook County: Report of the Cook County Juvenile Court Juvenile Justice Division, 2009. Circuit Court of Cook County, Chicago. http://www.cookcountyjustice.org/sites/www .cookcountyjustice.org/files/assets/JJ\%20Annual\%20Report_Final_Printer.pdf.

Deitch, Michele, Rebecca Breeden, and Ross Weingarten. 2012. Seventeen, Going on Eighteen: An Operational and Fiscal Analysis of a Proposal to Raise the Age of Juvenile Jurisdiction in Texas. American Journal of Criminal Law 40:1-67.

Dixon, Ken. 2009. Change Sought in How Justice System Treats Teens. Danbury News-Times, April 3. http://www.newstimes.com/news/article/Change-sought -in-how-state-justice-system-treats-118054.php.

Fagan, Jeffrey. 1996. The Comparative Advantage of Juvenile versus Criminal Court Sanctions on Recidivism among Adolescent Felony Offenders. Law and Policy 18:77-114.

Fagan, Jeffrey, Aaron Kupchik, and Akiva Liberman. 2007. Be Careful What You Wish For: Legal Sanctions and Public Safety among Adolescent Felony Offenders in Juvenile and Criminal Court. Research Paper No. 03-61. Columbia Law School, New York.

Farrington, David P., Rolf Loeber, and James C. Howell. 2012. Young Adult Offenders: The Need for More Effective Legislative Options and Justice Processing. Criminologv and Public Policy 11:729-50.

Feld, Barry C. 1999. Bad Kids: Race and the Transformation of the Juvenile Court. Studies in Crime and Public Policy. New York: Oxford University Press.

Ferdinand, Pamela. 2002. Seventeen an Awkward Age, N.H. Juvenile Justice Finds: In Reversal, State Moves to Raise Criminal Adulthood to 18. Washington Post, March 27, p. A03.

Fox, James Alan. 1996. Trends in Juvenile Violence: A Report to the United States Attorney General on Current and Future Rates of Juvenile Offending. Bureau of Justice Statistics, Washington, DC.

Gruber, Jonathan. 2000. Disability Insurance Benefits and Labor Supply. Lournal of Political Economv 108:1162-83.

Hawken, Angela, and Mark Kleiman. 2009. Managing Drug Involved Probationers with Swift and Certain Sanctions: Evaluating Hawaii's HOPE. Report prepared for the National Institute of Justice, Washington, DC. 
Heller, Sara, Jens Ludwig, Thomas J. Miles, and Jonathan Guryan. 2011. How Can We Know If Juvenile Justice Reforms Are Worth the Cost? Knowledge brief. Models for Change Research Initiative. John D. and Catherine T. MacArthur Foundation, Chicago.

Henrichson, Christian, and Valerie Levshin. 2011. Cost-Benefit Analysis of Raising the Age of Juvenile Jurisdiction in North Carolina. Unpublished report. Vera Institute of Justice, New York.

Hjalmarsson, Randi. 2009. Crime and Expected Punishment: Changes in Perceptions at the Age of Criminal Majority. American Law and Economics Review 11:209-48.

Hlavach, Laura E. 2013. Panel Proposes 17-Year-Old Suspects Only Be Charged as Juveniles. Decatur Herald and Review, February 27.

Illinois Juvenile Justice Commission. 2013. Raising the Age of Juvenile Court Jurisdiction: The Future of 17-Year-Olds in Illinois' Justice System. Illinois Juvenile Justice Commission, Springfield. http://ijjc.illinois.gov/sites/ijjc.illinois.gov/ files/assets/IJJC\%20-\%20Raising\%20the\%20Age\%20Report.pdf.

Ingram, David. 2007. Report: Treat 16-, 17-Year-Olds as Juveniles. Charlotte News and Observer, December 6.

Jensen, Eric L., and Linda K. Metsger. 1994. A Test of the Deterrent Effect of Legislative Waiver on Violent Juvenile Crime. Crime and Delinquency 40:96-104.

Kurlychek, Megan C., and Brian D. Johnson. 2004. The Juvenile Penalty: A Comparison of Juvenile and Young Adult Sentencing Outcomes in Criminal Court. Criminology 42:485-515.

Landenberger, Nana A., and Mark W. Lipsey. 2005. The Positive Effects of Cognitive-Behavioral Programs for Offenders: A Meta-analysis of Factors Associated with Effective Treatment. Iournal of Experimental Criminology 1:451-76.

Lanza-Kaduce, Lonn, Jodi Lane, Donna M. Bishop, and Charles E. Frazier. 2005. Juvenile Offenders and Adult Felony Recidivism: The Impact of Transfer. Lournal of Crime and Iustice 28:59-77.

Lee, David S., and Justin McCrary. 2009. The Deterrence Effect of Prison: Dynamic Theory and Evidence. Working Paper No. 189. Princeton University, Center for Economic Policy Studies, Princeton, NJ.

Lemmon, John H., Thomas L. Austin, P. J. Verrecchia, and Matthew Fetzer. 2005. The Effect of Legal and Extralegal Factors on Statutory Exclusion of Juvenile Offenders. Youth Violence and Iuvenile Iustice 3:214-34.

Loeffler, Charles E., and Ben Grunwald. 2015. Processed as an Adult: A Regression Discontinuity Estimate of the Crime Effects of Charging Nontransfer Juveniles as Adults. Lournal of Research in Crime and Delinquency 52:890-922.

Lord, Steve. 2008. Bill to Change Juvenile Age Haunts County. Aurora Beacon News, June 4.

Loughran, Thomas A., Edward P. Mulvey, Carol A. Schubert, Laurie A. Chassin, Laurence Steinberg, Alex R. Piquero, Jeffrey Fagan, Sonia Cota-Robles, 
Elizabeth Cauffman, and Sandy Losoya. 2010. Differential Effects of Adult Court Transfer on Juvenile Offender Recidivism. Law and Human Behavior $34: 476-88$.

McCord, Joan, Cathy Spatz Widom, and Nancy A. Crowell, eds. 2001. Juvenile Crime, Juvenile Justice. Washington, DC: National Academy Press.

McGowan, Angela, Robert Hahn, Akiva Liberman, Alex Crosby, Mindy Fullilove, Robert Johnson, Eve Moscicki, LeShawndra Price, Susan Snyder, Farris Tuma, Jessica Lowy, Peter Briss, Stella Cory, and Glenda Stone. 2007. Effects on Violence of Laws and Policies Facilitating the Transfer of Juveniles from the Juvenile Justice System to the Adult Justice System: A Systematic Review. American Iournal of Preventive Medicine 32:7-28.

Moore, Martha T. 2011. Fewer Kids Sent to Adult Courts-Budget Woes, Deaths Spur Rule Changes for Juveniles. USA Today, March 16.

Morse, Travis. 2007. County Opposes State Juvenile Offender Bill. Freeport JournalStandard, March 21.

Mulvey, Edward P., and Carol A. Schubert. 2012. Transfer of Juveniles to Adult Court: Effects of a Broad Policy in One Court. Bulletin No. NCJ 232932. Washington, DC: Department of Justice, Office of Juvenile Justice and Delinquency Prevention. http://www.ojjdp.gov/pubs/232932.pdf.

Myers, David L. 2003. The Recidivism of Violent Youths in Juvenile and Adult Court: A Consideration of Selection Bias. Youth Violence and Iuvenile Iustice 1:79-101.

Puzzanchera, Charles, and Crystal Robson. 2014. Delinquency Cases in Juvenile Court, 2010. Juvenile Offenders and Victims National Report Series fact sheet. February. Department of Justice, Office of Juvenile Justice and Delinquency Prevention, Washington, DC.

Redding, Richard E. 2010. Juvenile Transfer Laws: An Effective Deterrent to Delinquency? Juvenile Justice Bulletin No. NCJ 220595. Washington, DC: Department of Justice, Office of Juvenile Justice and Delinquency Prevention.

Risler, Edwin A., Tim Sweatman, and Larry Nackerud. 1998. Evaluating the Georgia Legislative Waiver's Effectiveness in Deterring Juvenile Crime. $\underline{R e}$ search on Social Work Practice 8:657-67.

Roman, John. 2006. The Economic Impact of Raising the Age of Juvenile Jurisdiction in Connecticut. Remarks before the Judiciary and Appropriations Committee, Connecticut General Assembly, February 21. http://www.urban .org/sites/default/files/alfresco/publication-pdfs/900959-The-Economic -Impact-of-Raising-the-Age-of-Juvenile-Jurisdiction-in-Connecticut.PDF.

Rubin, H. Ted. 2003. Juvenile Justice: Policies, Practices, and Programs. Vol. 1. Kingston, NJ: Civic Research Institute.

Schwartz, John. 2013. A Bid to Keep Youths out of Adult Prisons. New York Times, October 28. http://www.nytimes.com/2013/10/29/us/a-bid-to-keep-youths -out-of-adult-prisons.html. 
Singer, Simon I., and David McDowall. 1988. Criminalizing Delinquency: The Deterrent Effects of the New York Juvenile Offender Law. Law and Societv Review 22:521-36.

Steiner, Benjamin, and Emily Wright. 2006. Assessing the Relative Effects of State Direct File Waiver Laws on Violent Juvenile Crime: Deterrence or Irrelevance? Journal of Criminal Law and Criminology 96:1451-77.

Tanenhaus, David S. 2002. The Evolution of Juvenile Courts in the Early Twentieth Century: Beyond the Myth of Immaculate Construction. Pp. 42-73 in A Century of Juvenile Justice, edited by Margaret K. Rosenheim, Franklin E. Zimring, David S. Tanenhaus, and Bernardine Dohrn. Chicago: University of Chicago Press.

- 2004. Juvenile Justice in the Making. New York: Oxford University Press.

Timberlake, George W. 2009. Juvenile Crime Bill Provides "One Last Chance” for Teens. Elgin Courier News, January 6, p. A5.

Winner, Lawrence, Lonn Lanza-Kaduce, Donna M. Bishop, and Charles E. Frazier. 1997. The Transfer of Juveniles to Criminal Court: Reexamining Recidivism over the Long Term. Crime and Delinquency 43:548-63.

Wiser, Mike. 2009. County Sees Red in Law Change on Juvies. Rockford Register Star, December 27, pp. 1C, 2C.

Zimring, Franklin E. 1998. American Youth Violence. New York: Oxford University Press. 